\title{
Research on the Impact of Private Enterprises' Performance of Social Responsibility on Enterprise Competitiveness*
}

\author{
He Zhu \\ Peking University HSBC Business School \\ Beijing, China 100872
}

Yang Yu

Research Institute of Maritime Silk-Road (RIMS) Peking University HSBC Business School Beijing, China

\author{
Xiaoxu Kong** \\ College of Business Administration \\ Capital University of Economics and Business \\ Beijing, China 100070 \\ **Corresponding Author \\ Yi Guo \\ School of Economics \\ Beijing Technology and Business University \\ Beijing, China 100048
}

\begin{abstract}
This paper takes the data of 452 private listed companies from 2008 to 2012 as a sample, and uses the generalized method of moment (GMM) of panel data to empirically study the impact of private enterprises' performance of social responsibility and enterprise basic competitiveness. The results show that private enterprises' performance of their responsibilities to the government, suppliers, public welfare and the environment will have a significant positive impact on the basic competitiveness of enterprises. At present, private enterprises' performance of their obligations to shareholders, creditors and employees has no significant effect on the basic competitiveness of enterprises. However, from the perspective of the lagging effect of corporate social responsibility, private enterprises have a lagging effect on the impact of shareholders' social responsibility on their basic competitiveness.
\end{abstract}

Keywords-private enterprise; enterprise social responsibility; competitiveness; generalized method of moment (GMM)

\section{INTRODUCTION}

In recent years, the academic community has basically agreed that companies should assume responsibility for the government, employees, consumers and other stakeholders. In practice, companies often lack sufficient motivation to fulfill their social responsibilities. The performance of social responsibility tends to increase the operating costs of the company, and ultimately reduce the company's net profit. Especially for private enterprises, enterprise survival is the top priority. Social responsibility investment is more like a "face-saving project" or "overflow of compassion". However, no matter what kind of enterprise wants to

*[Fund Project] The research on the short-term effects of environmental protection inspectors on the Chinese economy commissioned by the Ministry of Ecology and Environment of the People's Republic of China. maintain long-term sustainable development, strengthening its basic competitiveness is the only way. If private enterprises fulfill their social responsibilities and contribute to the improvement of their basic competitiveness, it is reasonable for private enterprises to actively fulfill their social responsibilities. This leads to the question that this article attempts to answer. Shall the performance of private enterprise of social responsibility be conducive to improving the basic competitiveness of enterprises?

Early scholars generally believe that enterprise social responsibility would weaken the competitiveness of enterprises. The neoclassical economics school represented by Friedman (1970) believes that enterprise social responsibility will consume the resources of enterprises, increase the cost of enterprises, and will be at a disadvantage compared with competitors who do not consider social responsibility. Aupperle, Carroll, and Hatfield (1985) believed that if companies allocated capital and resources in other social responsible activities (eg, philanthropy, environmental protection, community development, etc.), the enterprises may relatively be a relative disadvantage compared with those rarely perform social responsibilities. This will reduce the advantages of enterprises in the competition.

With the development of stakeholder theory and its integration with enterprise social responsibility theory, more and more research shows that corporate social responsibility can enhance the trust of stakeholders in the company, increase the company's financial performance and enhance the competitiveness of the company. Cornell and Shapiro (1987) validated the hypothesis of social impact. They argue that if the company fails to meet the interests of other stakeholders, it will trigger market fears. Therefore, it will increase the risk premium of the company, ultimately, leading to higher costs or losing the opportunity of profit. 
The enterprise social responsibility will win the support of stakeholders, reduce transaction costs, enhance the reputation of the company, and enhance the competitiveness of the company. Preston and O'Bannon (1997) used comprehensive theoretical analysis framework to analyze the data of 67 large US companies from 1982 to 1992, and found a strong positive correlation between corporate social responsibility and corporate performance. In addition, studies have shown that the impact of corporate social responsibility on corporate competitiveness is not positive. Griffin and Mahon (1999) conducted a survey of 51 literature on the relationship between corporate social responsibility and financial performance. It confirmed that there were 33 articles having positive correlations, 19 articles having negative correlations, and 9 articles having no correlation.

In China, there are few papers using empirical analysis methods to directly study the impact of corporate social responsibility on corporate competitiveness. Most of the research focuses on the impact of corporate social responsibility on corporate financial performance. Based on the data of 46 listed companies from 2003 to 2007, Wen Subin (2008) used the panel data model to study the relationship between corporate social responsibility and financial performance. He finds that listed companies in China have begun to pay attention to social responsibility. However, the disclosure information of social responsibility is very less. Most corporate social responsibility variables have a negative impact on current financial performance. In the long run, corporate social responsibility has a positive impact on their financial performance. Wei Ruqing and Tang Fangcheng (2013) introduced social capital as an intermediate variable based on the perspective of stakeholders. They used AMOS and SPSS tools to empirically test the relationship between corporate social responsibility performance and corporate financial performance. The study believes that there is no significant negative correlation between corporate social responsibility performance and short-term financial performance. However, there is a significant positive correlation between corporate social responsibility performance and long-term financial performance. From the perspective of social capital accumulation, it clarifies the internal motivation and mechanism of corporate social responsibility. Zhang Zhaoguo, Jin Xiaocui and Li Gengtai (2013) used the systematic GMM method to study the problem. The lagstage and current corporate social responsibility have a significant positive impact on financial performance. Yin Kaiguo, Liu Xiaoqin and Chen Huadong (2014) focused on the endogenous problems that were generally neglected in the empirical research on the relationship between corporate social responsibility and financial performance. Under the hypothesis of corporate social responsibility, the current corporate social responsibility has has significant positive impact on current corporate financial performance, and vice versa. Under the endogenous hypothesis of corporate social responsibility, the current corporate social responsibility and current financial performance have mutual influence and mutual cause and effect. The intertemporal regression results are not significantly different from the current review results.

In addition, there are differences in the relationship between corporate social responsibility and financial performance of state-owned enterprises and private enterprises. Wang Wencheng and Wang Shihui (2014) studied the correlation between social responsibility and corporate performance of Chinese state-owned enterprises. The empirical research results show that there is a linkage effect between social responsibility and corporate performance of state-owned enterprises. Also, the two items complement each other and promote each other. Zhang Jian's (2010) research on listed private enterprises in Shanghai stock market in the Yangtze River Delta region shows that private enterprises' performance of social responsibility in both government and environmental protection can promote the improvement of financial performance, and the performance of social responsibility in several aspects such as employees, investors, public welfare and law cannot promote the improvement of financial performance.

The representative studies on the relationship between corporate social responsibility and competitiveness are the papers of Zhang Xu, Song Chao and Sun Yaling (2010). They conducted an empirical analysis of the situation of listed companies in the pharmaceutical industry. According to the study, the early performance of corporate social responsibility will enhance the competitiveness of current enterprises, especially the performance of social responsibility in the past three years significantly affects the competitiveness of enterprises. Enterprises have different roles in social responsibility for different stakeholders. Responsibility for shareholders, governments and suppliers will significantly enhance the competitiveness of enterprises. There is no correlation between the responsibility and competitiveness of creditors, and the responsibility of enterprises to employees will weaken the competitiveness of enterprises.

In summary, the enterprises' fulfillment of social responsibility is beneficial to their own development, which has been accepted by most scholars. However, the current research has the following three aspects. First, most of the research samples are in a single industry for a specific period of time, leading to a lack of generality in the conclusions of the study. According to the research on samples from different industries in different periods, there are differences in the effectiveness of enterprises in fulfilling social responsibilities among different stakeholders. Secondly, there are more concerns about the financial performance of corporate social responsibility, and there is no emphasis on the impact of corporate social responsibility on basic competitiveness. Finally, there is no clear distinction between private enterprises and stateowned enterprises. In previous studies, the research conclusions of the full sample of listed companies are difficult to apply to the research object of this study private enterprises. 
The innovations of this paper are mainly reflected in three points. First is to select all private enterprises of Ashare listed companies from 2008 to 2012 as samples, which excludes the sample influence of state-owned enterprises and avoids the conclusion bias caused by industrial characteristics. Second, from the perspective of basic competitiveness, combined with the characteristics of private enterprises, in-depth analysis of the impact of private enterprises' performance of social responsibility on their basic competitiveness can make up for the current research on the implementation of social responsibility of private enterprises. The second is to use a more advanced methodthe generalized method of moment (GMM). It is to effectively solve the endogeneity problem of variables. The research conclusions are more effective.

The rest of the paper is organized as follows: the second part is the research hypothesis, the third part is the model setting and the applicability of the generalized moment method, the fourth part is the empirical analysis, and the fifth part summarizes the research.

\section{RESEARCH HYPOTHESIS}

This paper uses Wen Subin's classification method (2008) on stakeholders from the perspective of multi-capita symbiosis - capital form classification. The method divides the stakeholders of the enterprise into four categories according to the different forms of capital invested by the stakeholders into the enterprise: monetary capital stakeholders, human capital stakeholders, social capital stakeholders and ecological capital stakeholders. Corporate fulfillment of social responsibilities to various stakeholders can increase the competitiveness of enterprises to varying degrees. Sometimes this effect is intertemporal. In the following, the research hypothesis of this paper will be made from the perspective of private enterprises' impact on the basic competitiveness of four types of stakeholders.

\section{A. The Impact of Fulfilling the Responsibility of Monetary Capital Stakeholders on the Basic Competitiveness}

The monetary capital stakeholders of an enterprise mainly include shareholders and creditors.

Only when the company fulfills its responsibilities to shareholders and is committed to realizing the preservation and appreciation of shareholders' funds. When shareholders can obtain positive economic profits in the long run, the company can gain the trust of investors and obtain continuous capital investment from shareholders. The enterprises can have the capital base of production and operation, and enhance the basic competitiveness of enterprises. Conversely, if the enterprise can not fulfill its responsibilities to shareholders, it will result in long-term negative investment income of shareholders. The shareholders will consider withdrawing funds. This will affect the production and operation activities of enterprises, and weaken basic competitiveness of enterprises. Therefore, we can propose the following hypothesis:
H1: The private enterprises' fulfillment of responsibility to shareholders has a significant positive impact on the competitiveness of enterprises.

A creditor is an institution or individual that provides repayment of financing to an enterprise. The assets of the enterprise include equity assets and debt assets. The enterprise is inseparable from the support of external funds in production and operation. The creditors are important stakeholders of the enterprise. If enterprises can protect the interests of creditors, they can enhance their reputation. When enterprises have capital needs, they can obtain loans from banks, which can guarantee the source of funds in production and operation. It is helpful to enhance the basic competitiveness of enterprises. On the other hand, if the enterprise fails to fulfill its responsibilities to the creditor, infringes on the interests of the creditor, and fails to perform the obligation to repay the principal and interest, it will lose the capital investment from the creditor, affecting the development of the enterprise and weakening the basic competitiveness of the enterprise. Therefore, the following hypothesis is proposed:

$\mathrm{H} 2$ : The private enterprises' fulfillment of the responsibility to creditors has a significant positive impact on the competitiveness of enterprises.

\section{B. The Impact of Fulfilling the Responsibility of Human Capital Stakeholders on the Basic Competitiveness}

The human capital stakeholders of an enterprise mainly refer to the employees of the enterprise.

If the company actively fulfills its responsibilities to employees, provides employees with a healthy and comfortable working environment, reasonable salary and related job training, etc., it can increase employees' loyalty and sense of belonging to the company, and improve employees' enthusiasm for work. Therefore, the enterprises can obtain the competitiveness. On the other hand, if the company does not fulfill its responsibilities to employees, there are phenomena such as not paying wages on time, not training employees, compulsory overtime or deducting overtime pay, etc., it will cause dissatisfaction and negative completion, which will affect the improvement of the company's basic competitiveness. Therefore, the following hypothesis is proposed:

H3: The fulfillment of the responsibility of private enterprises for employees has a significant positive impact on the basic competitiveness of enterprises.

\section{The Impact of Fulfilling the Responsibility of Social Capital Stakeholders on the Basic Competitiveness}

Corporate social capital stakeholders mainly include government departments, suppliers, customers and the public. Considering that it is difficult to express the responsibility to customers with relevant financial indicators, the usual practice is to adopt a way of distributing questionnaires to customers to study customer's satisfaction, which reflects the performance of the company to customers. The subjectivity is too strong during the implementation 
process. It is quite different from the study of other stakeholders in this paper. Therefore, when analyzing the impact of private enterprises on the responsibility of social capital stakeholders to the basic competitiveness, this paper selects three stakeholders: government, suppliers and public welfare.

As the main body of supervision and provision of social public services, the government influences the implementation of enterprise plans through mandatory prohibition or complicated approval procedures. On the other hand, the government guides the business direction of enterprises and controls the production scale of the company through macro-control policies. Therefore, the performance of the responsibility of the private enterprise to the government must have major impact on the development and competitiveness of the company. The following hypothesis is proposed:

H4: The fulfillment of the responsibility of the private enterprise to the government will have significant positive impact on the basic competitiveness of the enterprise.

The supplier is in the upstream of the company, and is responsible for providing raw materials, machinery and equipment for the production of the company. It is an important stakeholder of the company. If the company can fulfill its responsibilities to the supplier, such as establishing a fair and reasonable supply contract with the supplier, and paying the payment on time to improve the payable turnover rate, it can establish a long-term and stable cooperative relationship with the supplier, which is conducive to the production and operation of the enterprise. The transaction costs and procurement costs negotiated with the suppliers can be reduced. The suppliers will also provide high-quality and low-cost services for the enterprises. The basic competitiveness of the enterprises can be effectively improved. Therefore, the following hypothesis is proposed:

H5: The fulfillment of the responsibility of private enterprises for suppliers has significant positive impact on the basic competitiveness of enterprises.

The public welfare activities of enterprises can effectively enhance the public image of enterprises. Under the same conditions, consumers generally give priority to products or services provided by enterprises that are enthusiastic about charitable donations, poverty alleviation, and student-supporting activities. It can improve business profits and the basic competitiveness of enterprises. Therefore, the following hypotheses are proposed for private enterprises to fulfill their responsibilities for public welfare:
H6: The fulfillment of the responsibility of private enterprises for public welfare will have significant positive impact on the basic competitiveness of enterprises.

\section{The Impact of Fulfilling the Responsibility of Ecological Capital Stakeholders on the Basic Competitiveness}

The ecological capital stakeholders of the enterprise mainly refer to the stakeholders who pay attention to the ecological contribution of the enterprise, mainly the natural environment, that is, the environmental responsibility of the enterprise. Nowadays, the society pays more and more attention to topics such as energy conservation, emission reduction and environmental protection. The expenditure on environmental protection of enterprises can increase the public's recognition of enterprises, and it can also enhance the basic competitiveness of enterprises to a certain extent. Therefore, the following hypothesis is proposed:

H7: The private enterprises' fulfillment of environmental responsibility will have significant positive impact on the basic competitiveness.

\section{E. The Lagging Effect of the Enterprises' Performance of Social Responsibility on the Basic Competitiveness}

The investment of private enterprises in social responsibility may not be effective immediately, and it may take some time to have an impact on the basic competitiveness of enterprises, that is, there is lagging effect. Therefore, the early investment of corporate social responsibility may have a positive impact on current basic competitiveness of the enterprise. Then, the author puts forward the hypothesis:

H8: The impact of private enterprises' responsibilities on various stakeholders on the basic competitiveness of enterprises is lagging behind.

\section{MODEL SETTING AND APPLICABILITY OF GENERALIZED METHOD OF MOMENT}

\section{A. The Definitions of Variable}

1) Explained variable: The explained variables are the basic competitiveness of the enterprise, and the practice of China industry and enterprise competitiveness research center of Chinese Academy of Social Sciences is adopted. The index weights of the enterprise competitiveness monitoring system are shown in the following "Table I".

TABLE I. INDEX WEIGHT OF THE BASIC COMPETITIVENESS MONITORING SYSTEM OF LiSTED COMPANIES IN SHANGHAI AND SHENZHEN

\begin{tabular}{|c|c|c|c|c|c|}
\hline Factor & Index & Weight & Factor & Index & Weight \\
\hline \multirow{4}{*}{$\begin{array}{l}\text { Scale } \\
\text { factor }\end{array}$} & Sales revenue & 19 & \multirow{7}{*}{$\begin{array}{l}\text { Efficienc } \\
\text { y factor }\end{array}$} & Net profit margin & 8 \\
\hline & Net assets & 10 & & Total asset contribution rate & 8 \\
\hline & net margin & 15 & & Full labor efficiency & 6 \\
\hline & Weight subtotal & 44 & & Export revenue accounts for the proportion & \\
\hline \multirow{3}{*}{$\begin{array}{l}\text { Growth } \\
\text { factor }\end{array}$} & Sales revenue growth rate in the past three years & 16 & & of sales revenue & 5 \\
\hline & Net profit growth rate in recent three years & 13 & & Weight subtotal & 27 \\
\hline & Weight subtotal & 29 & & Weight subtotal & 21 \\
\hline
\end{tabular}


2) Explanatory variables: Combined with Wen Subin's (2008) variable selection principle and the quantifiability of the variable indicators and the availability of data in the actual operation, the following seven explanatory variables were selected: basic earnings per share, interest payment rate, and employee profitability, book income tax rate, account payable turnover rate, main business tax and surcharge rate and social donation expenditure rate. The explanatory variables are summarized as follows ("Table II"):

TABLE II. SUMMARY TABLE OF EXPLANATORY VARIABLES

\begin{tabular}{|c|c|c|c|c|}
\hline \multicolumn{2}{|c|}{ Variable type } & Variable name & Variable meaning & $\begin{array}{c}\text { Variable calculation } \\
\text { method }\end{array}$ \\
\hline \multirow{2}{*}{$\begin{array}{l}\text { Responsibility } \\
\text { monetary } \\
\text { stakeholders }\end{array}$} & $\begin{array}{l}\text { Responsibility } \\
\text { shareholders }\end{array}$ & Stockholder & $\begin{array}{lll}\begin{array}{l}\text { Basic } \\
\text { share }\end{array} & \text { earnings per } \\
\end{array}$ & Net profit / total share capital \\
\hline & $\begin{array}{l}\text { Responsibility } \\
\text { creditors }\end{array}$ & Creditor & Interest payout rate & $\begin{array}{l}\text { Average amount of interest } \\
\text { expense/liabilities }\end{array}$ \\
\hline $\begin{array}{l}\text { Responsibility to human } \\
\text { capital stakeholders }\end{array}$ & $\begin{array}{l}\text { Responsibility } \\
\text { employees }\end{array}$ & Staff & Employee profitability & $\begin{array}{l}\text { Cash/business income paid to } \\
\text { employees }\end{array}$ \\
\hline \multirow{3}{*}{$\begin{array}{l}\text { Responsibility to social } \\
\text { capital stakeholders }\end{array}$} & $\begin{array}{l}\text { Responsibility to the } \\
\text { government }\end{array}$ & Government & $\begin{array}{l}\text { Main business tax } \\
\text { and additional rate }\end{array}$ & $\begin{array}{l}\text { Main business tax and } \\
\text { additional / total operating } \\
\text { income }\end{array}$ \\
\hline & $\begin{array}{l}\text { Responsibility to } \\
\text { suppliers }\end{array}$ & Supplier & $\begin{array}{ll}\text { Accounts } & \text { payable } \\
\text { turnover rate }\end{array}$ & $\begin{array}{l}\text { Operating cost / average } \\
\text { amount of accounts payable }\end{array}$ \\
\hline & $\begin{array}{l}\text { Responsibility to public } \\
\text { welfare }\end{array}$ & Public & $\begin{array}{l}\text { Social donation } \\
\text { expenditure rate }\end{array}$ & $\begin{array}{l}\text { Social donation expenditure / } \\
\text { total operating income }\end{array}$ \\
\hline $\begin{array}{l}\text { Responsibility } \\
\text { ecological } \\
\text { stakeholders }\end{array}$ & $\begin{array}{l}\text { Responsibility to the } \\
\text { environment }\end{array}$ & Environment & $\begin{array}{l}\text { Environmental } \\
\text { expenditure expense } \\
\text { rate }\end{array}$ & $\begin{array}{l}\text { Environmental expenditure } \\
\text { expenses / total operating } \\
\text { income }\end{array}$ \\
\hline
\end{tabular}

It should be noted that the indicators selected by enterprises for eco-capital stakeholders (mainly the environment) are "environmental expenses expenditure rate" (environmental expenses expenditure/main business income). However, most enterprises only discloses the ways and forms of fulfilling environmental responsibility in annual reports or the responsibility report of corporate society. There is no specific quantification. The sample size of the available data is small. If the "environmental cost expenditure rate" is included in the panel data analysis, the total sample capacity will be reduced. Therefore, the indicator is not included in the panel data analysis, and the cross-sectional data regression analysis method is adopted after the GMM of the dynamic panel data model.

\section{B. Sample Selection and Data Source}

Taking the A-share listed companies in the CSMAR database "China Private Listed Companies Research Database" from 2008-2012 as a sample, the listed companies in the financial industry, ST-type and listed companies with missing data were excluded. The final sample was panel data of 452 listed companies in 5 years.

The enterprise's basic competitiveness data comes from Jin Bei's "China Enterprise Competitiveness Report". The relevant data of corporate social responsibility comes from the Ruisi Financial Research Database and CSMAR Financial Research Database.

\section{Model Setting}

$$
\begin{aligned}
& \text { competitivenes } \mathrm{S}_{\mathrm{i}}=\boldsymbol{\beta}_{0}+\boldsymbol{\beta}_{1} * \text { Stockholder }_{\mathrm{it}}+\boldsymbol{\beta}_{2} * \text { Creditor }_{\mathrm{it}}
\end{aligned}
$$

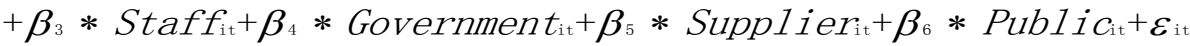

According to the research hypothesis H1-H6, substituting the variables selected in the previous model into the model, the basic model studied in this paper is as follows: $\beta_{0}$ is the intercept term, $\beta_{1}-\beta_{6}$ is the responsibility to the shareholders, the responsibility to the creditors, the responsibility to the employees, the regression coefficient corresponding to the responsibility of the government, the responsibility to the supplier and the responsibility for the public interest, $\varepsilon$ it is a random interference term, the subscript $\mathrm{i}$ indicates the $\mathrm{i}$-th enterprise, and the subscript $\mathrm{t}$ indicates the $\mathrm{t}$-th year.

\section{Discussion on the Applicability of Generalized Method of Moment}

In the past, scholars used the ordinary least squares method for regression analysis when they studied the relationship between corporate social responsibility and corporate competitiveness. Although it also reflected the impact of corporate social responsibility on competitiveness on various stakeholders, they did not consider the estimation bias caused by the endogeneity problem of the variable. And the selected explanatory variables only represent the maximum investment of the enterprise to all stakeholders, and can not fully reflect the role of the social responsibility fulfilled by the enterprise on the basic competitiveness of the enterprise.

In recent years, for the research of panel data, the GMM model is widely used at home and abroad. GMM is also known as generalized method of moments, is a parameter estimation method based on the fact that the actual parameters of the model satisfy certain moment conditions, and is the generalization of the moment method. As long as 
the model is set correctly, it is always possible to find several moment conditions that the actual parameters of the model satisfy and use GMM estimation. Traditional econometric estimation methods, such as ordinary least squares method, instrumental variable method and maximum likelihood method, have their own limitations. That is, its parameter estimator must be reliable estimator when meeting certain hypotheses, such as the random error term of the model obeys normal distribution or known distribution. GMM does not need to know the exact distribution information of the random error term, and allows the random error term to have heteroscedasticity and sequence correlation. Therefore, the obtained parameter estimation is more effective than other parameter estimation methods.

In addition, Rufetal (2001) and other scholars have found that the impact of corporate social responsibility investment on corporate competitiveness is lagging behind. At the same time, this lag is not only reflected in the interpretation of the variable to the dependent variable, but also in the impact of the previous dependent variable on the current dependent variable. In other words, the precompetitiveness of the company will have an impact on the current competitiveness. Therefore, the research in this paper needs to add the lag term of the dependent variable to the explanatory variable, but this will inevitably cause endogeneity problems. In the dynamic panel model, the delayed period of the explained variable as an explanatory variable is likely to cause the explanatory variable being correlated with the random disturbance term, which leads to the biased and inconsistent parameter estimation. And it may affect the final test result. Arellano and Bond (1991), Blundell and Bond (1998) proposed GMM estimation, which solved the above problems well according to the setting of moment conditions. The basic dynamic panel data model is as the following:

$$
Y_{i t}=\alpha_{1}+Y_{i t-1}+\sum_{i=1}^{n} \alpha_{i} x_{i t-1}+\varepsilon_{i t}
$$

Among them, $Y_{i t}$ is dependent variables, $x_{i t-1}$ is independent variable, $\alpha_{i}$ is coefficient, $\varepsilon_{i t}$ is random disturbance item.

\section{EMPIRICAL ANALYSIS}

\section{A. GMM Estimation of Dynamic Panel Data Model}

1) Stationarity test of sequence: In order to avoid "quasi-regression", it is necessary to perform a unit root test on the original variable sequence before analyzing the data to judge the station's stationarity. In this paper, the independent sample IPS test was used to test the stationarity of the data at a significant level of 5\% (Im, Pesaran and Shin, 1993). The results are shown in "Table III". It is found that all variable sequences are stationary, and generalized method of moment (GMM) can be performed.
TABLE III. Root Test Results of SEQUENCE

\begin{tabular}{|l|l|l|l|}
\hline \multicolumn{1}{|c|}{ Variable } & $\begin{array}{c}\text { Statistic } \\
\text { Statistic } \\
\text { value }\end{array}$ & $\begin{array}{c}\text { Prob. } \\
\text { accompany } \\
\text { probability }\end{array}$ & Conclusion \\
\hline Competitiveness & -11.4454 & 0.0000 & stationary \\
\hline Stockholder & -21.9138 & 0.0000 & stationary \\
\hline Creditor & $-1.00 \mathrm{E}+15$ & 0.0000 & stationary \\
\hline Staff & -28.0524 & 0.0000 & stationary \\
\hline Government & -4.09288 & 0.0235 & stationary \\
\hline Supplier & -26.0603 & 0.0000 & stationary \\
\hline Public & -3.66479 & 0.0001 & stationary \\
\hline
\end{tabular}

2) Model estimation result: The dynamic variable panel data model is built by the explained variable competitiveness. The second-order lag value of the competitiveness and the orthogonal transformation value of the original explanatory variables in the model are used as the tool variables, and the model is estimated by the GMM method. The results are shown in "Table IV".

TABLE IV. GMM Estimation Results of the Panel Data Model

\begin{tabular}{|l|l|l|l|l|}
\hline \multicolumn{1}{|c|}{ Variable } & Coefficient & \multicolumn{1}{|c|}{$\begin{array}{c}\text { Standard } \\
\text { deviation }\end{array}$} & \multicolumn{1}{|c|}{ T value } & $\begin{array}{l}\text { Accompany } \\
\text { probability }\end{array}$ \\
\hline $\begin{array}{l}\text { competitiveness(- } \\
\text { 1) }\end{array}$ & 0.001522 & 0.000974 & 1.561611 & 0.1186 \\
\hline Stockholder & -0.178551 & 0.104956 & -1.701199 & 0.0891 \\
\hline creditor & -0.963006 & 0.516731 & -1.863650 & 0.0626 \\
\hline staff & 0.000622 & 0.005279 & 0.117730 & 0.9063 \\
\hline government & 11.07746 & 5.912855 & 1.873453 & 0.0612 \\
\hline supplier & 0.004927 & 0.002057 & 2.395082 & 0.0168 \\
\hline public & 12.33865 & -10.44437 & -1.181368 & 0.0377 \\
\hline J statistic $=0.009785$ & & & \\
\hline
\end{tabular}

3) Model over-identification test: It is judged whether the estimation result obtained by the above generalized method of moment is valid, and it is judged by whether the setting of the tool variable is effective. J statistic can be used to test whether the over-recognized moment condition is true, $\mathrm{nJ} \sim \chi^{2}(\mathrm{LK})$. In the model of this paper, $\mathrm{n}=452, \mathrm{~L}=6$, $\mathrm{K}=2, \mathrm{~nJ}=4.42282<\chi^{2}(4)=9.48773$, accepting the original hypothesis that the tool variable setting is valid and the over-recognition moment condition is true, and the estimation result obtained by the generalized method of moment is effective.

4) Interpretation of model results: By observing the parameter estimation results in the "Table VII", we can find:

The parameters estimation results for the responsibility of government, supplier, and public interest are respectively $11.07746,0.004927$, and 12.33865, greater than 0 . The accompany probability values of the t-test are less than 0.1 . Less than the significant level of $10 \%$, the responsibility of private enterprises to the government, suppliers and public welfare is significantly positively related to the competitiveness of the enterprise, that is, private enterprises fulfill their responsibilities to the government, suppliers and public welfare has has a positive impact on the basic 
competitiveness of enterprises. The hypotheses H4, H5 and H6 are supported.

The parameter estimations for the responsibility of shareholder and creditor are -0.178551 and -0.963006 , respectively, less than zero, and the accompany probability value of the t-test is less than 0.1 . Less than significant level of $10 \%$, the performance of private enterprises in fulfilling their responsibilities to the government and the responsibilities of creditors is significantly negatively related to the competitiveness of the enterprise. That is to say, private enterprises fulfill their responsibilities to the government and their responsibilities to creditors have a negative impact on their basic competitiveness. Hypothesis $\mathrm{H} 1$ and $\mathrm{H} 2$ are not supported.

The accompanying probability value of the employee's liability t-test is $0.9063>0.1$, which does not pass t-test at a significant level of $10 \%$. Hypothesis $\mathrm{H} 3$ is not supported.

From the results of GMM analysis, the performance of private enterprises in fulfilling their responsibilities to employees has not had a significant impact on the basic competitiveness of enterprises, and the performance of private enterprises' responsibilities to shareholders and creditors will have a negative impact on the basic competitiveness of enterprises in the current period. From the analysis of the theoretical part of the previous article, it can be seen that the role of enterprises in fulfilling their responsibilities to stakeholders may have a lag in the role of enterprise fundamental competitiveness. Therefore, in order to verify the hypothesis H8, the liability for shareholders, the responsibility for creditors and the responsibility for employees are delayed. In the first phase, stockholder(-1), creditor(-1) and staff(-1) are added to the model as explanatory variables. The author should re-investigate GMM and analyze the lag of private enterprises in fulfilling the impact of social responsibility on the basic competitiveness of enterprises. The results are shown in "Table V".

TABLE V. GMM ESTIMATION RESULTS OF THE LAG-PERIOD EXPLAINED VARIABLES

\begin{tabular}{|l|l|l|l|l|}
\hline \multicolumn{1}{|c|}{ Variable } & Coefficient & \multicolumn{1}{|c|}{$\begin{array}{c}\text { Standard } \\
\text { deviation }\end{array}$} & \multicolumn{1}{|c|}{ T value } & $\begin{array}{l}\text { Accompany } \\
\text { probability }\end{array}$ \\
\hline competitiveness(-1) & 0.000779 & 0.000609 & 1.279520 & 0.2009 \\
\hline Stockholder & -0.059456 & 0.070747 & -0.840398 & 0.4008 \\
\hline creditor & -0.618643 & 0.377529 & -1.638664 & 0.1015 \\
\hline staff & -0.014329 & 0.006071 & -2.360115 & 0.0184 \\
\hline government & 6.305579 & 3.805178 & 1.657105 & 0.0977 \\
\hline supplier & 0.002477 & 0.001759 & 1.407879 & 0.1594 \\
\hline public & -3.919569 & 5.721360 & -0.685076 & 0.4934 \\
\hline Stockholder(-1) & 0.305046 & 0.075324 & 4.049793 & 0.0001 \\
\hline creditor(-1) & -0.034176 & 0.030161 & -1.133117 & 0.2574 \\
\hline staff(-1) & -0.021489 & 0.004998 & -4.299869 & 0.0000 \\
\hline
\end{tabular}

Observing the estimation results in "Table V", it can be found that the coefficient value corresponding to stockholder(-1) is $0.305046>0$, and the accompanying probability value of $t$ test is $0.0001<0.1$. With significant level at $10 \%$, it will pass t-test. The corresponding coefficient of stockholder(-1) is not significantly zero. There is a lagging effect on the impact of private enterprises' fulfillment of shareholder's responsibility on the basic competitiveness of enterprises.

However, the coefficient value corresponding to the creditor(-1) has not passed the test, which indicates that the performance of private enterprise's responsibility for the creditor has no significant impact on the basic competitiveness of the enterprise. The coefficient value corresponding to the obtained $\operatorname{staff}(-1)$ is less than 0 , which indicates that the impact of the private enterprise's performance on the employee's responsibility on the basic competitiveness of the enterprise is still reversed. The effect of the private enterprise to the creditor and the employee to fulfill the social responsibility is not significant in a short time. It will be significant in long run.

In summary, the hypothesis $\mathrm{H} 8$ passed the test in the analysis of the impact of private enterprises' performance on shareholders' responsibility on basic competitiveness. However, from the analysis of the impact of creditors and employees' social responsibility on basic competitiveness, hypothesis $\mathrm{H} 8$ fails the test.

\section{B. Regression Analysis of Cross-section Data}

1) Regression analysis: The regression analysis of the panel data in the previous paper does not include the responsibility of the enterprise for ecological capital stakeholders (mainly the environment). The "environmental cost expenditure rate" (environmental cost expenditure/main business income, environment) is used as an explanatory variable. It no longer distinguishes the year. And it has made the cross-sectional data regression of the explained variable competitiveness. Eviews output results are shown in "Table VI".

TABLE VI. REGRESSION ANALYSIS RESULTS OF CROSS-SECTIONAL DATA

\begin{tabular}{|l|l|l|l|l|}
\hline Variable & Coefficient & $\begin{array}{c}\text { Standard } \\
\text { deviation }\end{array}$ & T value & $\begin{array}{l}\text { Accompany } \\
\text { probability }\end{array}$ \\
\hline C & 0.29133 & 0.124822 & 2.333975 & 0.0339 \\
\hline environment & 0.036247 & 0.006078 & 5.963639 & 0.0467 \\
\hline
\end{tabular}

In "Table VI", the corresponding coefficient to the explanatory variable environment is 0.036247 , which is positive, and the accompanying probability value of the $t$ test is $\mathrm{P}=0.0339<0.05$, indicating that the variable is significant at the significant level of $5 \%$. That is, the environmental protection expenditure rate of the private enterprise increases by 1 percentage point, the enterprise's basic competitiveness will increase by 0.036247 , which confirms the correctness of the hypothesis H7. That is, the performance of private enterprises for the environment will have a positive impact on the basic competitiveness of enterprises. 
2) Heteroscedasticity test of regression model: In order to ensure that the parameter estimators of the regression equation have good statistical properties, there is an important assumption when using the ordinary least squares method to estimate the model: the random error terms in the total regression function have the same variance, that is, the same variance assumption. If the sample does not satisfy the assumption that the random error term has the same variance, the linear regression model is called heteroscedasticity. In this paper, the white test is used to test the sample heteroscedasticity. The results are shown in "Table VII":

TABLE VII. SAMPLE White Test Result

\begin{tabular}{|l|l|l|l|l|}
\hline \multicolumn{1}{|c|}{ Variable } & \multicolumn{1}{|c|}{ Coefficient } & \multicolumn{1}{|c|}{$\begin{array}{c}\text { Standard } \\
\text { deviation }\end{array}$} & \multicolumn{1}{|c|}{ T value } & \multicolumn{1}{c|}{$\begin{array}{c}\text { Accompany } \\
\text { probability }\end{array}$} \\
\hline $\mathrm{C}$ & 0.228312 & 0.100861 & 2.263629 & 0.04 \\
\hline environment & -0.7679 & 2.186639 & -0.35118 & 0.7307 \\
\hline environment ${ }^{\wedge}$ & 0.608122 & 3.960456 & 0.153548 & 0.8802 \\
\hline $\mathrm{R} 2=0.639538$ & \multicolumn{4}{|l}{} \\
\hline
\end{tabular}

It can be seen from "Table VII" that the White statistic n $\mathrm{R} 2=17 \times 0.639538=10.872146>\chi^{2}(1)=3.84$, the assumption that the model has the same variance cannot be rejected. The regression model does not have heteroscedasticity. Therefore, the results of regression analysis of cross-section data are reliable. Hypothesis 7 is verified, and the performance of responsibility of private enterprises to the environment will have a positive impact on the basic competitiveness of enterprises.

\section{CONCLUSION}

This paper uses the data of private listed companies to conduct empirical analysis, and finds that the performance of private enterprises' responsibilities to the government, suppliers, public welfare and the environment will have a significant positive impact on the basic competitiveness of enterprises. From the current perspective, the performance of private enterprises' responsibility to shareholders, creditors and employees has no significant effect on the basic competitiveness of enterprises. However, from the analysis of the lagging effect of corporate social responsibility, it is found that private enterprises have a lagging effect on the impact of shareholders' performance of social responsibility on their basic competitiveness.

The above research conclusions prove that the implementation of corporate social responsibility by private enterprises does contribute to the improvement of basic competitiveness. Therefore, enterprises should pay attention to the investment in corporate responsibility. At the same time, the conclusions of this paper also provide a certain basis for the decision-making of production and management of private enterprises. Since the impact of the performance of the responsibility of different social stakeholders on their basic competitiveness is different. The enterprises can have a certain focus on the distribution of social responsibility inputs. However, in the long run, if companies want to seek long-term development and obtain sustainable competitiveness, they should not ignore any stakeholder and pay attention to the comprehensive investment and development of corporate social responsibility.

\section{REFERENCES}

[1] Wen Subin, Fang Yuan. An empirical study on the relationship between corporate social responsibility and financial performance-A panel data analysis from the perspective of stakeholders[J]. China Industrial Economy, 2008, 10: 150-160.

[2] Tian Hong. Correlation between Corporate Social Responsibility and Corporate Performance_-Based on Empirical Data of China's communication industry[J]. Economic Management, 2009, 01: 72-79.

[3] Yang Ziye, Yin Kaiguo. An empirical study of corporate social performance affecting financial performance[J]. China Soft Science, 2009,11:109-118.

[4] Shi Junwei, Hu Lijun, Fu Haiyan. Corporate social responsibility, social capital and organizational competitive advantage: A strategic interaction perspective-An empirical study based on China's transitional experience[J]. China Industrial Economy, 2009, 11: 87-98.

[5] Zhang Jian. Research on the effectiveness of private enterprise's social responsibility driven financial performance[J]. Economic Forum, 2010,01:161-163.

[6] Chen Ke, Li Shantong. The impact of corporate social responsibility on financial performance: A perspective of key elements [J]. Statistical Research, 2010, 07: 105-111.

[7] Guo Yi. Research on the implementation mode of social responsibility of Chinese small and medium enterprises[J]. Seeker, 2015,05:40-42.

[8] Tang Yan. A summary of empirical research on the economic causes of corporate social responsibility under the guidance of stakeholders[J]. Management World, 2011, 08: 184-185.

[9] Zhang Zhaoguo, Liang Zhigang, Yin Kaiguo. Research on corporate social responsibility from the perspective of stakeholders[J]. China Soft Science, 2012, 02: 139-146.

[10] Wang Qi, Wu Chong. Empirical analysis of the dynamic effect of corporate social responsibility financial effect_-Based on life cycle theory[J]. China Management Science, 2013, S2: 542-548.

[11] Wei Ruqing, Tang Fangcheng. The mechanism of CSP-CFP: An empirical study based on stakeholders[J]. Management Science, 2013, 06: $12-24$.

[12] Qi Dianwei, Nuo Min,Wang Yujiao. Research on the impact of corporate social responsibility on financial performance in China[J]. Economic Aspects, 2013, 11: 82-84.

[13] Yin Kaiguo, Liu Xiaoqin, Chen Huadong. Research on the relationship between corporate social responsibility and financial performance based on endogenous__Evidence from Chinese listed companies[J]. China Soft Science, 2014, 06: 98-108.

[14] Zhang Zhaoguo, Jin Xiaocui, Li Gengqin. An empirical study on the inter-temporal impact of corporate social responsibility and financial performance[J]. Accounting Research, 2013, 08: 32-39+96.

[15] Wang Wencheng, Wang Shihui. Research on the correlation between social responsibility and enterprise performance of Chinese stateowned enterprises[J]. China Soft Science, 2014, 08: 131-137. 
[16] Friedman M. The social responsibility of business is to increase its profit. New York Times Magazine, 1970,13:122-126.

[17] Aupperle K, Carroll A B, Hatfield J D. An empirical examination of the relationship between corporate social responsibility and profitability. Academy of Management Journal, 1985, 28(2): 446-463.

[18] Cornell Bradford, Alan Shapiro. Corporate stakeholders and corporate finance. Financial Management, 1987: 5-14.

[19] Preston, Lee E; O'Bannon, Douglas P. The corporate social-financial performance relationship: A typology and analysis, Business and Society36.4 (Dec 1997): 419-429.

[20] Griffin J, Mahon J. The corporate social performance and corporate financial performance debate: Twenty-five years of incomparable research. Business and Society. 1997, 36(1):5-31. 